\title{
Analisis Warna dan Bentuk terhadap Kemampuan Visual Anak Autis Pada Fasilitas Pendidikan
}

\author{
*Saffanah Zhahirah Aflah ${ }^{1}$, Anisa ${ }^{2}$ \\ ${ }^{1,2}$ Arsitektur, Fakultas Teknik, Universitas Muhammadiyah Jakarta, Indonesia \\ 2016460046@ftumjac.id
}

*Alamat korespondensi, Masuk: 03 Maret 2020, Direvisi: 31 Maret 2020, Diterima: 10 April 2020

\begin{abstract}
ABSTRAK: Fasilitas pendidikan dapat berfungsi dengan sangat efektif apabila ruang dengan penggunanya dapat berinteraksi melalui pendekatan indera visual, yaitu dengan menciptakan ruang pada bangunan yang didukung oleh susunan elemen yang dapat memberikan pengalaman pada penggunanya, terutama pada anak autis. Anak dengan gangguan autis dapat dibedakan dalam 2 klasifikasi, yaitu anak dengan gangguan hipersensori dan hiposensori. Perbedaan keduanya tentu sangat signifikan dan memiliki daya tangkap yang berbeda terhadap warna yang bersifat menstimulus dan memengaruhi emosi. Anak dengan gangguan autis juga merupakan anak yang sangat sensitif dengan lingkungannya. Oleh karena itu penting memerhatikan bentuk pada elemen-elemen bangungan dan ruangan agar tetap ramah terhadap anak autis. Dengan menggunakan metode deskriptif kualitatif berdasarkan teori Mukhtar dan didukung oleh teori yang relevan lainnya seperti teori oleh Magda Mostafa, Ching, Milne dan Coulter. Penelitian ini memfokuskan terhadap aplikasi elemen warna dan bentuk yang terdapat pada bangunan fasilitas pendidikan bagi anak-anak autis. Hal ini yang menjadi dasar analisis dengan mengacu kepada kebutuhan terhadap anak autis berdasarkan klasifikasinya. Dalam penelitian ini banyak ditemukan elemen warna dan bentuk yang bersifat netral. Bahkan program ruang yang tersedia juga belum memenuhi kebutuhan bagi anak-anak autis. Kesimpulan yang didapatkan dari penelitian ini adalah aplikasi warna dan bentuk sangat penting mengingat bahwa anak dengan gangguan autis memiliki masalah interaktinya masing-masing. Pesan yang tersampaikan terutama secara visual dapat berbeda-beda ketika diterima oleh masing-masing anak. Maka dari itu hal ini dapat dibantu dengan menciptakan kebutuhan ruang yang didukung dengan aplikasi elemen warna dan bentuk yang sesuai agar dapat membentuk suatu lingkungan belajar bagi anak autis. Dengan begitu ruangruang yang tercipta akan membentuk pengalaman tersendiri yang sesuai dengan bebutuhan bagi tiap anak.
\end{abstract}

Kata kunci: Fasilitas Pendidikan, Warna, bentuk, Autisme

\begin{abstract}
Educational facilities can function very effectively if space with its users can interact through the visual sensory approach, by creating space in buildings that are supported by an arrangement of elements that can provide experience to its users, especially in children with autism. Children with autistic disorders can be divided into 2 classifications, children with hypersensory and hyposensory disorders. The difference between the two is certainly very significant and has a different comprehension to colors that are stimulating and affect emotions. Children with autistic disorders are also very sensitive to their environment. It is therefore important to pay attention to the form of the building elements and the room in order to remain friendly to children with autism. By using qualitative descriptive methods based on Mukhtar's theory and supported by other relevant theories such as theories by Magda Mostafa, Ching, Milne and Coulter. This study focuses on the application of color and shape elements found in building educational facilities for children with autism. This is the basis of the analysis by referring to the needs of autistic children based on their classification. In this research, many elements of color and shape that are neutral are found. Even the available space program also does not meet the needs of autistic children. the conclusion drawn from this study is the application of color and shape is very important considering that children with autistic disorders have their own interaction problems. the messages conveyed especially visually can vary when received by each child. Therefore this can be helped by creating space requirements that are supported by the application of appropriate color and shape elements in order to form a learning environment for children with autism. That way the spaces created will form their own experiences that are suitable for the needs of each child.
\end{abstract}

Keywords: Educational Facility, Colour, Form, Autism 


\section{PENDAHULUAN}

Desain merupakan hal yang penting pada sebuah tahapan perancangan untuk menyampaikan fungsi bangunan secara visual. Menerapkan desain yang baik untuk mewujudkan tujuan tertentu dapat dilakukan dengan berbagai cara salah satunya dengan pemilihan elemen finishing bangunan yang tepat. Pemilihan warna dan bentuk yang tepat dapat memengaruhi desain dan efek psikologis yang akan timbul. Salah satu bangunan yang harus diperhatikan dalam pemilihan elemen finishingnya bangunan pendidikan. Terutama bangunan pendidikan bagi anak dengan gangguan autisme.

Fasilitas pendidikan bagi anak penyandang autis merupakan salah satu bangunan yang harus diperhatikan desainnya terutama pada bagian ruang-ruang dalam (interior), sebab ruang-rang tersebut akan sangat aktif digunakan. Sarana pendidikan dapat berfungsi dengan sangat efektif apabila ruang dengan penggunanya dapat berinteraksi melalui pendekatan indera visual, yaitu dengan menciptakan ruang pada bangunan yang didukung oleh susunan elemen yang dapat memberikan pengalaman pada penggunanya, terutama pada anak autis. Elemen yang dimaksud yaitu berupa warna dan bentuk.

Berdasarkan latar belakang tersebut, maka perlu dilakukan penelitian tentang penerapan warna dan bentuk terhadap kemampuan visual anak autis pada fasilitas pendidikan. Tujuan dari penelitian ini adalah untuk mengetahui tentang warna dan bentuk yang dapat diterapkan dalam sebuah ruang belajar agar bisa menjadi ruang yang efektif. Dengan pendekatan visual yang tepat, hal ini bermanfaat bagi para tenaga pengajar dan para murid agar dapat menciptakan suasana ruang belajar yang akan meningkatkan kualitas pendidikan bagi anak autis. Adapun manfaat dari penelitian ini diantaranya; dapat menambah wawasan terhadap warna dan bentuk, mengetahui pengaruh/hubungan warna dan bentuk terhadap visual pengguna, dan hasil dari penelitian ini dapat digunakan menjadi acuan saat mendesain fasilitas pendidikan terutama pada ruang belajar di sekolah bagi anak-anak berkebutuhan khusus

\section{DEFINISI AUTIS}

Autisme merupakan kelainan perkembangan saraf yang tidak dapat berkembang sempurna sejak lahir ataupun saat masa balita sehingga mempengaruhi fungsi otak. Karakteristis anak autis yaitu memiliki kesulitan berinteraksi sosial atau komunikasi yang normal sehingga mengakibatkan anak terisolasi dari lingkungan sosialnya dan masuk dalam dunia repetitif, aktivitas dan minat yang obsesif. [6]

Karakteristik anak autis dapat dilihat berdasarkan jenis masalah dan gangguan yang dialaminya. Karakteristik anak autis dideskripsikan dalam enam poin [8] yaitu: 1) Masalah dibidang komunikasi; 2) Masalah dibidang interaksi sosial; 3) Masalah dibidang kemampuan; 4) Masalah dibidang pola bemain; 5) Masalah perilaku; dan 6) Masalah emosi.

\section{DISFUNGSI SENSORI PADA ANAK AUTIS}

Menurut Mostafa (2008) Anak dengan gangguan autis biasanya menjadi sangat sensitif atau bahkan tidak responsif terhadap rangsangan dari sensoris/indera. Disfungsi sensori pada autis muncul dalam dua bentuk perilaku: [15] 1) Hipersensori merupakan anak dengan gangguan hipersensori memikili kepekaan lebih tinggi dalam menerima sensori sehingga anak akan cenderung berperilku berlebihan (hiperaktif) dan memiliki emosi yang cukup labil bahkan tantrum; 2) Hiposensori yaitu anak dengan gangguan hiposensori memiliki kekurangpekaan dalam menerima sensori sehingga menyebabkan anak menjadi lambat terhadap respon pada hal-hal yang terjadi di sekitar mereka sehingga biasanya mereka menjadi pasif. Perilaku ini biasanya mengalami emosi yang tidak tepat misalnya melamun, menangis dan tertawa tanpa sebab.

Berdasarkan kemampuan sensori visual, [3,14] dapat dibedakan sebagai berikut: 1) Hiper adalah melihat mengeliling dan susah fokus apabila terdapat distraksi visual di sekelilingnya, namun jika ada suatu benda kecil di antara kekosongan visual, ia lebih fokus ke benda tersebut, sehingga perlu meminimalisasi distraksi visual; 2) Hipo yaitu melihat dengan fokus jarak lebih dekat untuk menyadarkan di sekelilingnya diperlukan sesuatu yang menarik perhatian dan fokus pergerakan matanya menuju ke lingkungannya.

Anak dengan disfungsi sensori tidak dapat beradaptasi secara optimal, hal ini disebabkan karena fungsi syarafnya tidak mengembangkan proses untuk mengintegrasikan input sensorik dari lingkungannya. [11] 


\section{WARNA}

Warna berperan penting terhadap penampilan visual suatu ruang dan juga dapat menciptakan kamuflase suatu ruangan. Warna selain terbagi atas warna primer, sekunder dan tersier, warna juga digolongkan sesuai dengan temperaturnya. [9] seperti: a) Komposisi dari warna yang bersifat dingin (cool colors) seperti biru, menimbulkan perasaan tenang dan damai, tetapi juga dapat menimbulkan kesedihan; b) Komposisi warna hangat (warm colors) seperti merah atau oranye menimbulkan perasaan nyaman dan gembira; c) Komposisi warna gelap akan menimbulkan kesan yang misterius atau rasa takut; d) Warna - warna dengan intensitas yang tinggi terlihat menarik dan memicu terjadinya aktivitas.

Penggunaan warna di dalam proses komunikasi dapat dikategorikan sebagai pesan non verbal artifaktual melalui penampilan untuk membangun image atau citra tertentu terhadap diri kita. Pesan non verbal mempunyai makna yang universal (universal meaning) [12]

Warna dalam arsitektur biasanya untuk menekankan dan memperjelas karakter dari sebuah objek yang memberikan aksen pada bentuk dan bahan. Sedangkan berdasarkan fungsi psikologis warna dapat memberikan pengaruh tertentu pada sifat, perasaan, maupun jiwa seseorang. [7]

\section{BENTUK}

Menurut Vitruvius, tidak ada istilah bentuk. Bentuk, bagi Vitruvius, bila mau dikaitkan dengan fungsi/utilitas tentunya merupakan gabungan antara firmistas (technic) dengan venustas (beauty/delight). Bentuk dapat dikenali secara visual karena memiliki ciri-ciri sebagai berikut [2]: 1) Wujud: hasil konfigurasi tertentu dari permukaan-permukaan dan sisi-sisi bentuk; 2) Dimensi: dimensi suatu bentuk adalah panjang, lebar dan tinggi; 3) Warna: corak, intensitas dan nada pada permukaan suatu bentuk; 4) Tekstur: karakter permukaan suatu bentuk; 5) Posisi: letak relatif suatu bentuk terhadap suatu lingkungan atau medan visual; 6) Orientasi: posisi relatif suatu bentuk terhadap bidang dasar, arah mata angin atau terhadap pandangan seseorang yang melihatnya; 7) Visual: derajat konsentrasi dan stabilitas suatu bentuk.

Bentuk dapat diperkuat atau dilemahkan oleh bentuk lain. Untuk program-program fungsional pada bangunan biasanya membutuhkan gabungan beberapa elemen. Hal ini tidak berarti menjadi keterbatasan estetika. Arsitek dapat menghasilkan efek yang impresif dengan menggabungkan bentuk-bentuk. Misalnya dengan menggunakan pengulangan bentuk-bentuk yang sama dan berbagai cara lainnya.

\section{WARNA DAN BENTUK TERHADAP AUTIS}

Menurut Gheista Indina (2014) dalam jurnal "Penerapan Warna dan Cahaya pada Interior Ruang Terapi Dasar dengan Pendekatan Visual Anak Autis" mengklasifikasikan konsep warna terhadap disfungsi sensori anak autis [5], yaitu: 1) Hipersensori adalah konsep warna yang cocok digunakan untuk anak dengan gangguan hipersensori adalah kelompok warna yang teduh dimana akan memberikan efek menenangkan untuk anak. Contoh kelompok warna yang teduh adalah kelompok warna analogus. Misalnya antara hijau-biru, hijau kuning, biru-ungu, dan lain-lain; 2) Hiposensori yaitu konsep warna yang cocok digunakan untuk anak dengan gangguan hiposensori adalah kelompok warna yang cerah dan memberi efek ceria. Dengan ini akan membuat pengguna ruang (anak dengan gangguan hiposensori) terstimulasi dan dituntun untuk lebih aktif. Contoh kelompok warna yang ceria adalah kelompok warna komplementer atau warna yang saling melengkapi. Misalnya antara warna oranyemerah \& biru-hijau, oranye-kuning \& biru-ungu, dan lain-lain.

Konsep warna yang dimaksud dapat diaplikasikan pada ruang kelas/belajar, ruang terapi individu, ruang terapi kelompok atau ruang kegiatan lainnya.

Selain warna, ragam bentuk dan material juga dapat pengaruh terhadap anak autis. Bukan dari segi pengaruh visual, namun ragam bantuk dan material yang dimaksud akan berpengaruh dari segi keselamatan anak-anak autis sebagai penggunanya. Anak dengan gangguan autis sangatlah sensitif dalam segala hal. Termasuk dengan material dan bentuk yang ada di sekitar lingkungannya. Dalam pemilihan material sangat dianjurkan material yang bersifat sehat. Hal yang dimaksud adalah material yang aman dan mudah dibersihkan. Sebagai contoh, pemilihan cat pada dinding harus sangat diperhatikan. Karena ada kemungkinan jika salah memilih jenis cat, maka lapisan cat yang menempel dapat mengupas atau rontok. Sehingga berpotensi untuk terhirup dan mengendap di dalam tubuh. Begitu juga dengan hal lainnya seperti bentuk dan properti yang ada [13]. Mengingat anak dengan ganguuan autis sangat sensitif hingga dapat menyebabkan tantrum, maka perlu memperhatikan juga hal seperti bentuk dan 
properti yang ada di sekeliling. Benda atau properti yang ada haruslah yang bersifat ramah/aman. Benda yang dimaksud adalah benda yang tidak runcing/tidak tajam, benda yang lembut/lunak/tidak berbahaya apabila terjadi benturan dan tidak akan melukai anak.

Tabel 1. Konsep warna dan elemen bentuk terhadap disfungsi sensori

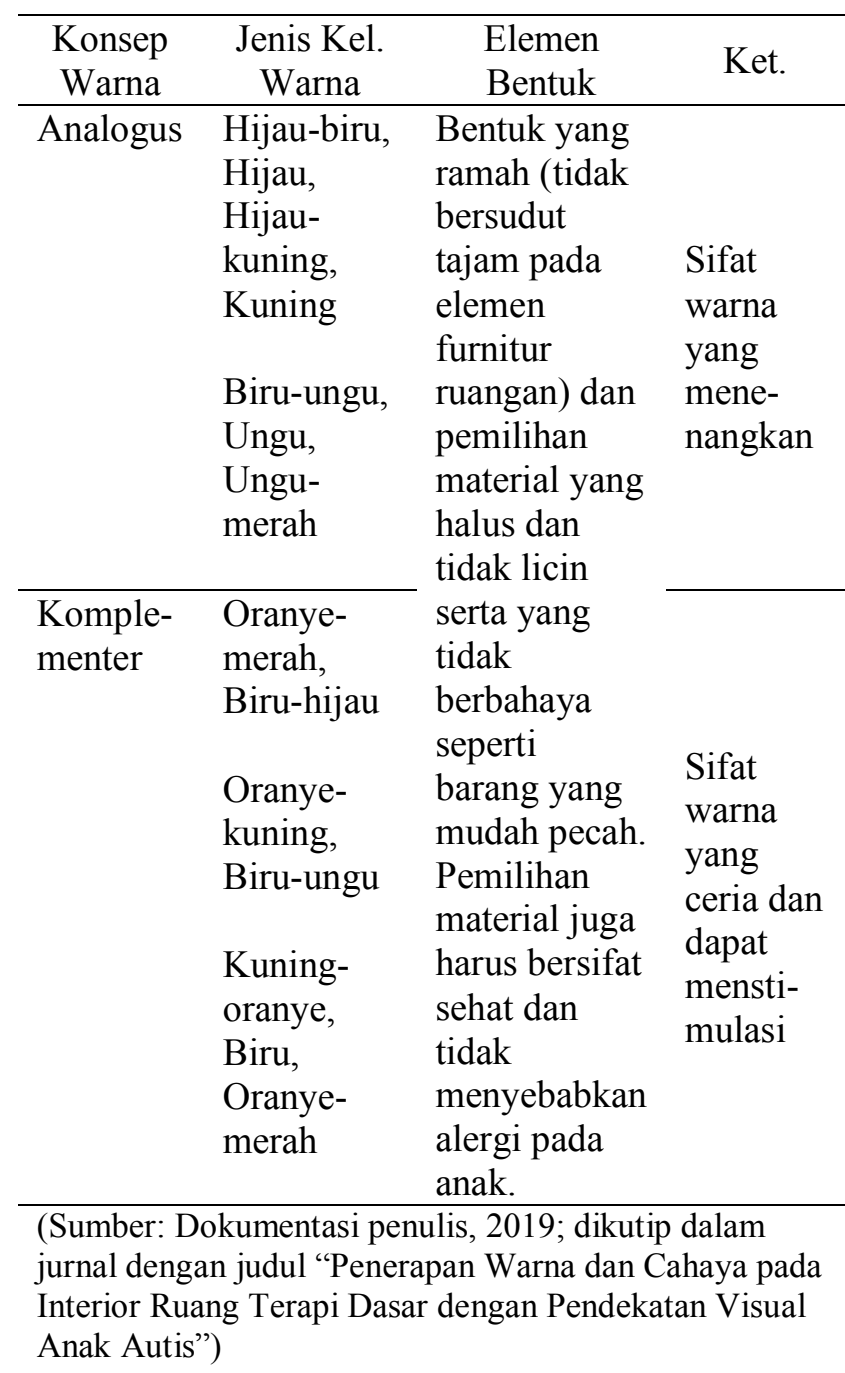

\section{METODE PENELITIAN}

Penelitian ini dilaksanakan dengan menggunakan metode deskriptif kualitatif, yaitu berusaha mendeskripsikan seluruh gejala atau keadaan yang ada, yaitu keadaan gejala menurut apa adanya pada saat penelitian dilakukan Penelitian deskriptif kualitatif berusaha mendeskripsikan seluruh gejala atau keadaan yang ada, yaitu keadaan gejala menurut apa adanya pada saat penelitian dilakukan. [16]

Data yang diperoleh merupakan data primer dimana pengumpulan data melalui observasi lapangan dan wawancara dengan pihak institusi. Dalam menganalisis data yang diperoleh untuk penelitian, maka digunakan metode deduktif dimana penarikan kesimpulan dari keadaankeadaan umum. Analisis ini dilakukan untuk mengetahui lebih dalam mengenai obyek yang diteliti berdasarkan permasalahan dan tujuan penelitian, serta berusaha untuk mengambil kesimpulan dari penelitian yang dilakukan.

Objek bangunan fasilitas pendidikan yang akan dibahas dalam penelitian ini yaitu President Special Needs Center (PSNC) dan Hope Special Needs Center (Hope School) yang merupakan sekolah bagi anak-anak berkebutuhan khusus, yakni autis. Kedua institusi tersebut dipilih sebagai sampel penelitian karena memiliki kriteria sebagai berikut:1) Objek penelitian merupakan bangunan pendidikan untuk anak autis; 2) Bangunan harus memiliki fasilitas yang menunjang bagi autis baik dari segi pendidikan maupun ruang terapi hingga fasilitas-fasilitas penunjang lainnya.

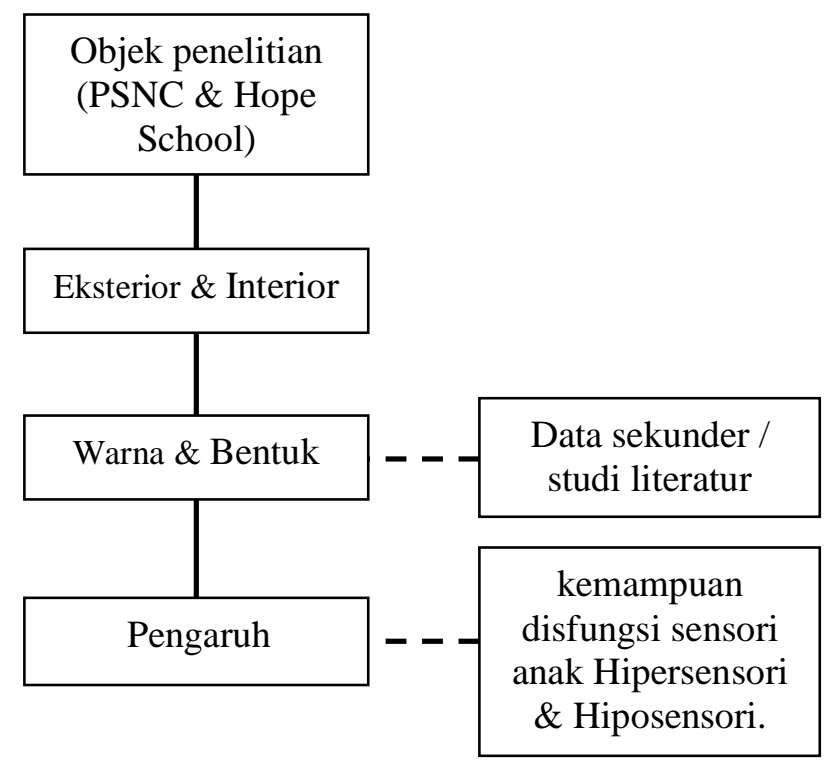

Gambar 1. Skema Analisis 
HASIL DAN PEMBAHASAN

\section{PRESIDENT SPECIAL NEEDS CENTER (PSNC) \\ President Special Needs Center (PSNC)} merupakan bangunan sekolah yang terletak di Cikarang, Bekasi. Bangunan ini memiliki massa bangunan yang sederhana dengan mengadopsi gubahan bentuk persegi panjang. Terdiri dari 1 lantai, sekolah ini memiliki taman sekaligus lapangan yang cukup. Warna yang diaplikasikan di sekolah ini didominasi dengan cat dinding berwarna cream.

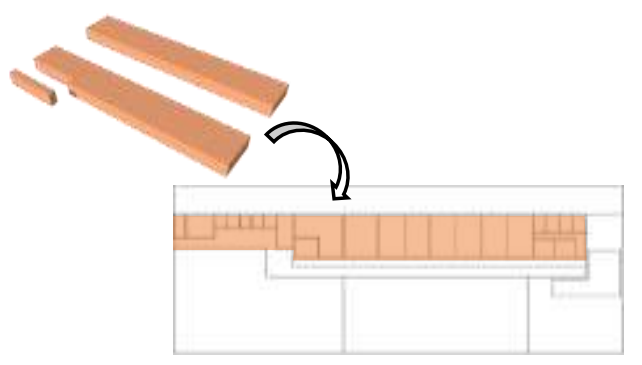

Gambar 2. Gubahan massa President Special Needs Center $(P S N C)$

\section{Eksterior}

Pada eksterior President Special Needs Center (PSNC) secara tipologi nampak seperti bangunan sekolah di Indonesia pada umumnya. Memiliki selasar single loaded yang dihadapkan ke area terbuka seperti taman/lapangan. Bentuk pada bangunan PSNC didominasi dengan elemen persegi. Seperti bentuk ruang-ruang yang tersedia, bentuk bukaan, maupun elemen pelengkap lainnya. Bentuk persegi menunjukan sesuatu yang rasional dan memiliki kesan netral. [18]

Warna yang mendominasi pada eksterior PSNC adalah warna cream. Warna cream dianggap netral karena merupakan campuran dari warna kuning yang bersifat ceria dengan warna putih. Sehingga menghasilkan warna pastel seperti cream yang memiliki sifat warna kalem dan juga menenangkan. [10]

Berdasarkan hasil wawancara dengan salah satu terapi di PSNC, sejauh ini pemilihan betuk persegi pada eksterior bangunan tidak terlalu memiliki dampak terhadap kemampuan visual anak autis baik itu hipersensori maupun hiposensori. Namum, warna cream yang diaplikasikan pada bangunan ini memberikan dampak dan membawa kesan tenang namun cerah pada psikologis penggunanya terutama anak-anak dengan disfungsi sensori baik hipersensori maupun hiposensori.

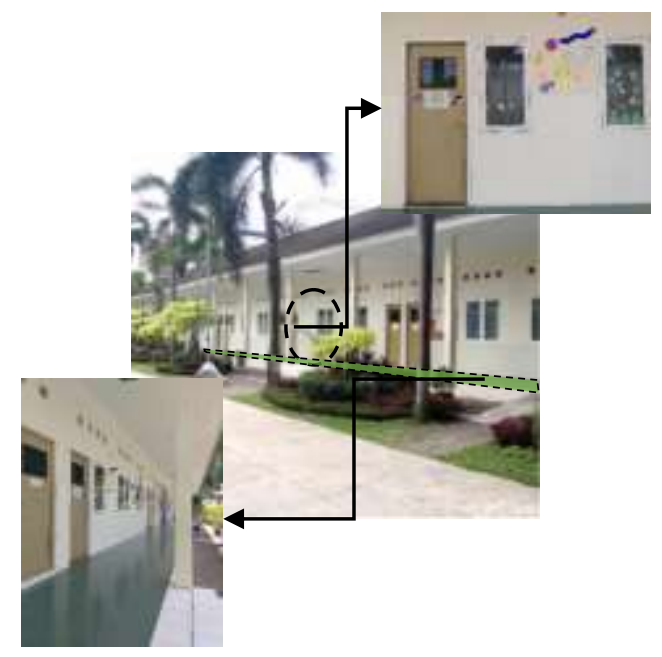

Gambar 3. Eksterior President Special Needs Center (PSNC)

Area terbuka/outdoor yang juga merupakan elemen eksterior di PNSC sudah cukup memadai. Pada area terbuka/outdoor terbagi 3 zona sehingga area ini memiliki fungsinya masing-masing yaitu area taman yang juga sebagai taman bermain dan area berkebun, lapangan yang digunakan untuk melakukan kegiatan olah raga dan upacara, serta area bermain lainnya berupa playground.

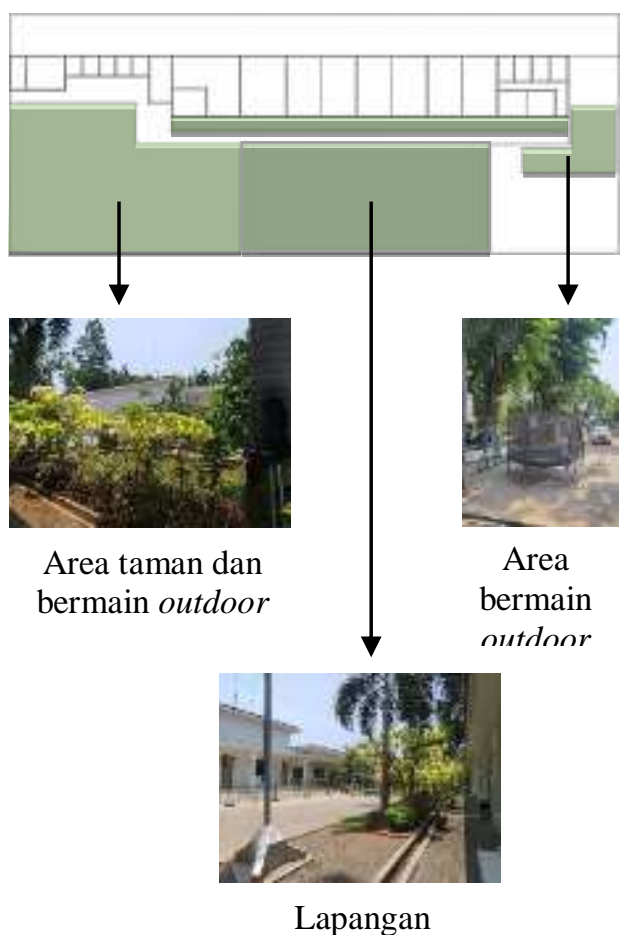

Gambar 4. Area terbuka/outdoor bagian eksterior President Special Needs Center (PSNC) 


\section{Interior}

Pada bagian interior President Special Needs Center (PSNC) tediri dari beberapa ruang dengan pembagian katagori area kelas, area terapi, area staff \& kepala sekolah, dan area service.

Pada area kelas terdapat 5 ruang dan memiliki tingkatan yang berbeda-beda. Mulai dari tingkatan yang dasar (ruang mampu rawat), tingkatan menengah (ruang mampu latih), dan tingkatan lanjut (ruang mampu didik). Kelima kelas tersebut didesain serupa. Pemilihan warna cream pada bagian interior area ini masih mendominasi karena memiliki sifat netral. Tidak hanya warna, bentuk dan layout ruang kelas ini pun di buat seragam. Hal ini berlaku sama terhadap ruang laboratorium komputer. Yang menjadi pembeda hanya tidak digunakannya material karpet pada ruang laboratorium komputer. Elemen bentuk yang ada pada masing-masing ruang kelas juga bukan merupakan desain atau material yang khusus. Masih ditemukan benda-benda yang keras terhadap benturan seperti dinding yang tidak dilapisi matras atau elemen lunak lainnya. Selain itu terdapat pula desain furniture yang masih memiliki sudut. Meski demikian, masih terdapat pula beberapa meja dan bangku yang rounded atau tidak memiliki sudut yang tajam.

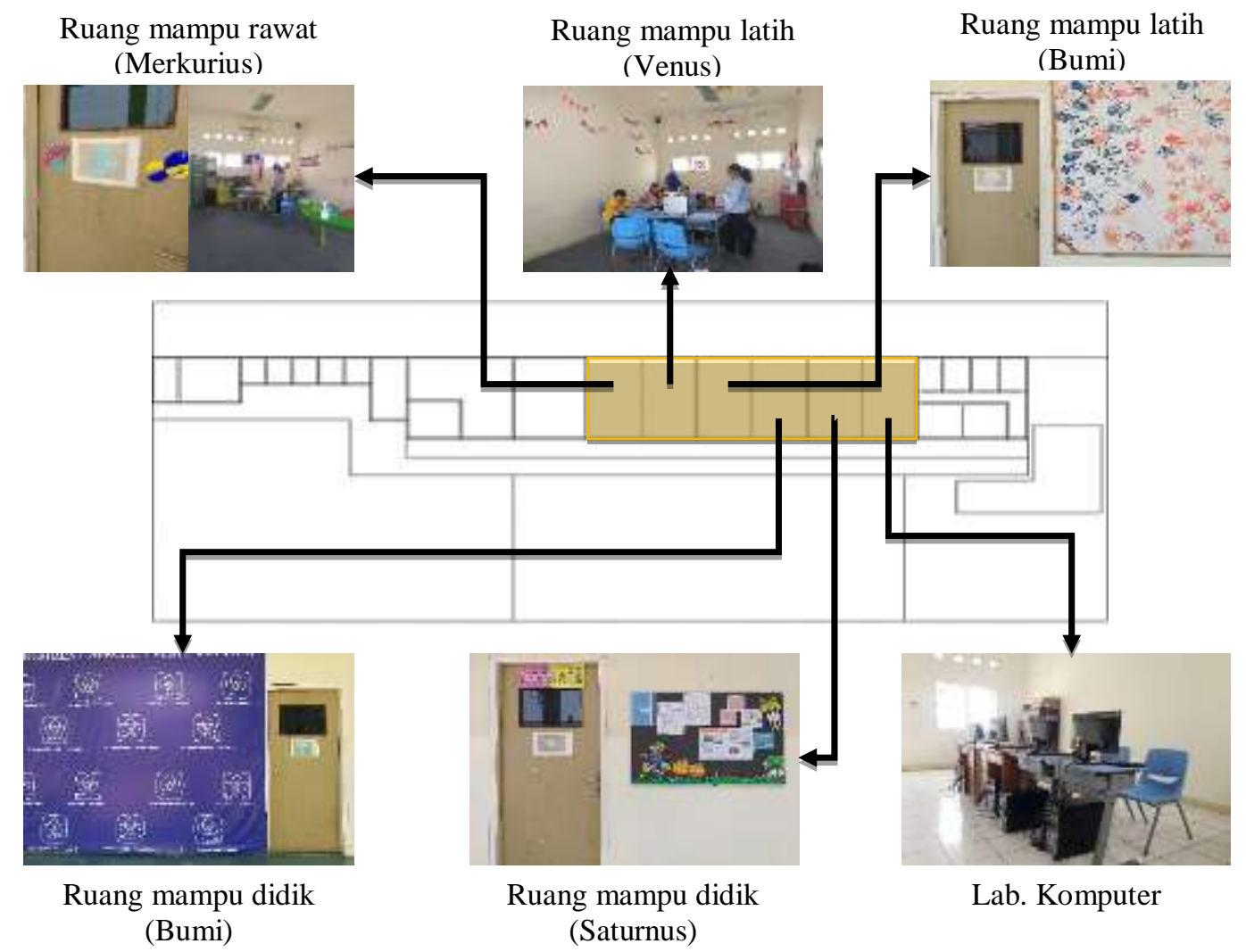

Gambar 5. Area kelas President Special Needs Center (PSNC)

Pada area terapi, terdapat 5 jenis ruang terapi yaitu ruang terapi sensori integrasi (SI), ruang terapi perilaku, ruang terapi wicara, ruang terapi music, dan ruang remedial teaching. Keempat ruang terapi selain ruang terapi SI, didesain serupa dengan masih menggunakan warna dasar cream dan diisi dengan kebutuhan yang berbeda-beda sesuai dengan jenis ruang terapi.

Sedangkan ruang terapi SI didesain secara khusus.
Pemilihan warna cream pada bagian interior ruang terapi ini masih mendominasi pada bagian dinding tetapi sudah diaplikasikan dengan matras yang lunak. Hal ini tentunya dapat mengurangi efek yang diakibatkan bila terjadi benturan. Ruang terapi SI bisa dikatakan yang paling menonjol karena memiliki banyak warna seperti warna hijau, biru, orange, dan diisi dengan barang yang beragam bentuk dan material yang lebih ramah. 


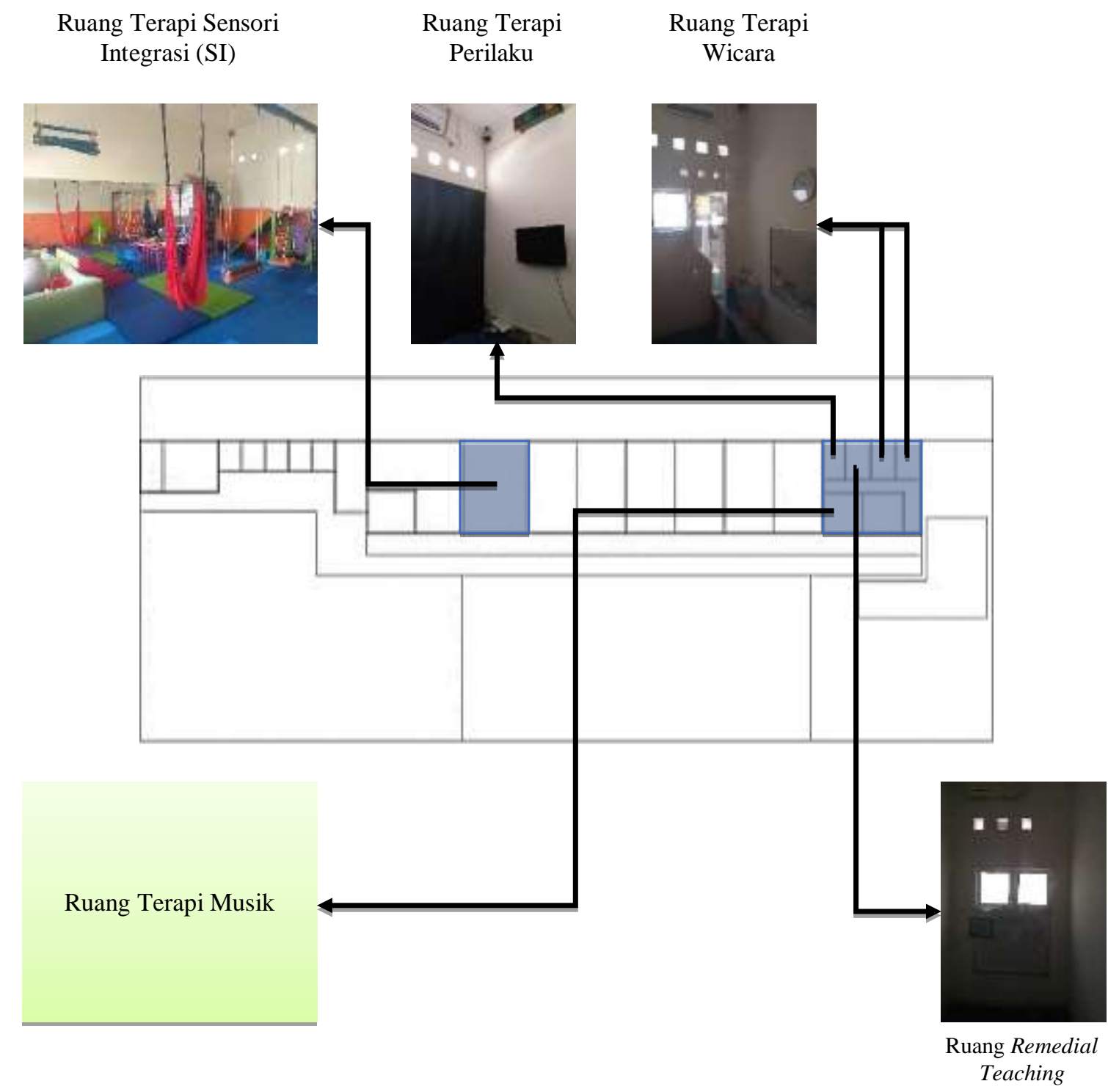

Gambar 6. Area terapi President Special Needs Center (PSNC) 
Ruang staff dan area service juga masih dengan warna cream sebagai warna dasar. Ruang staff merupakan area terbatas yang hanya terdapat aktifitas bagi staff itu sendiri, guru, dan kepala sekolah. Selain itu digunakan juga untuk menerima tamu dan bagi yang bekepentingan. Sehingga tidak warna khusus dan bentuk-bentuk tertentu pada ruang staff.

Bagian dari area service yang aktif digunakan adalah ruang makan dan dapur yang sekaligus juga menjadi tempat untuk kegiatan kelas memasak. Bentuk ruang makan dan dapur dibuat secara terbuka dan menghadap taman sehingga mendapatkan udara langsung. Selain itu, toilet yang ada juga tidak didesain secara khusus dari segi warna dan bentuk, terutama bagi anak-anak dengan disfungsi sensori. Ruang pantry yang tersedia hanya digunakan selain anak-anak. Begitu pula ruang gudang yang minim aktifitas orang.

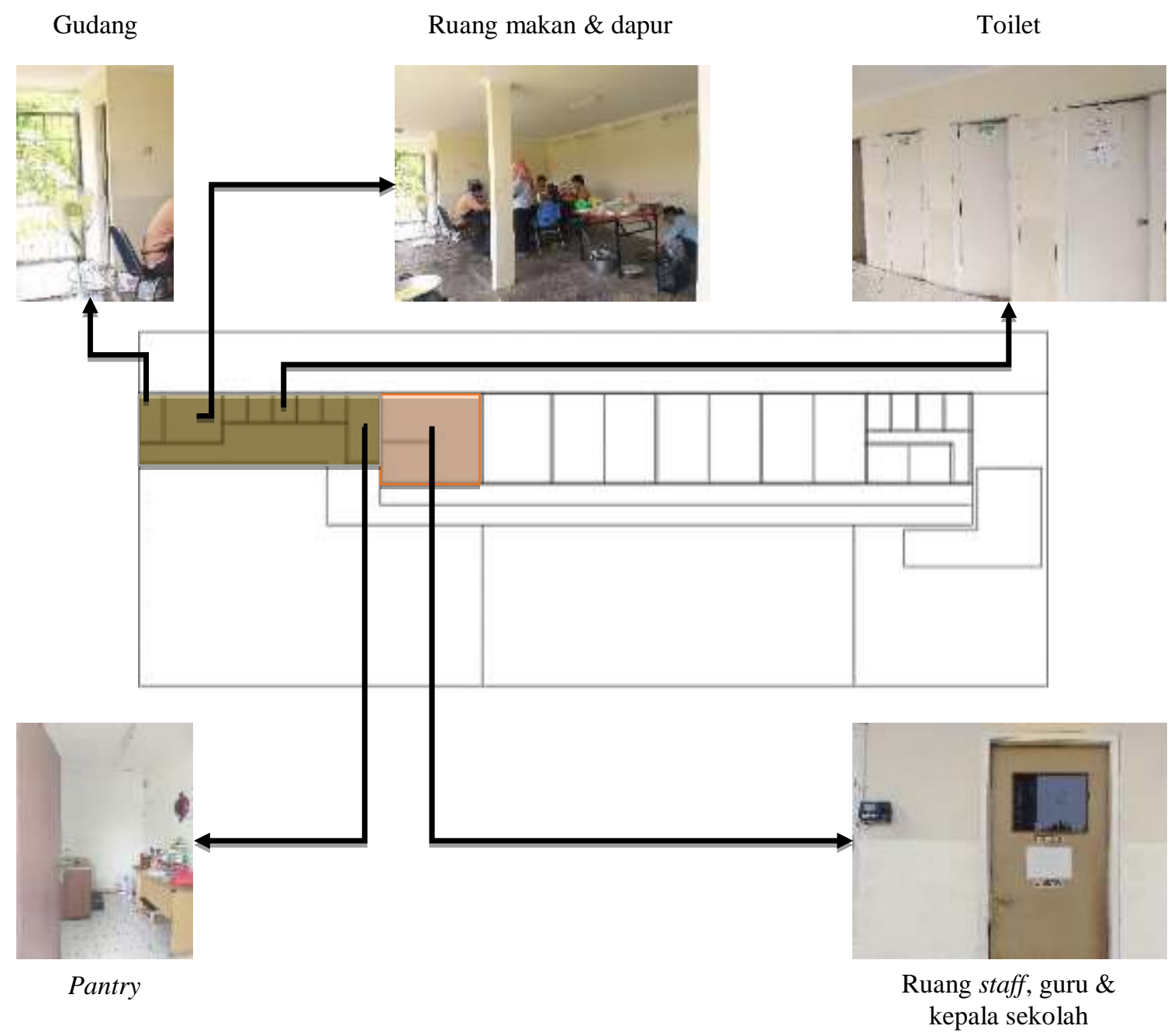

Gambar 7. Area service dan ruang staff President Special Needs Center (PSNC) 
HOPE SPECIAL NEEDS CENTER (Hope School)

Hope Special Needs Center (Hope School) merupakan bangunan sekolah yang terletak di kawasan bisnis. Bangunan ini merupakan gabungan dari 2 massa persegi panjang yang terdiri 5 lantai. Warna pada tampak bangunan ini adalah navy yang didapat dari warna kaca film yang menyelubungi bangunan, sedangkan pada bagian dalam bangunan ini warna yang diaplikasikan adalah variasi warna cream dengan berbagai tone yang berbeda dan beragam warna lainnya.
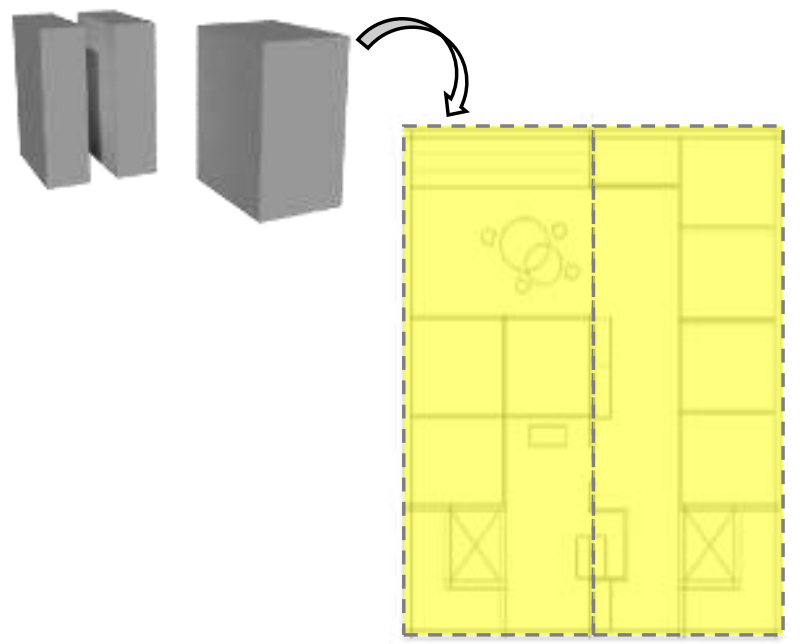

Gambar 8. Gubahan massa Hope Special Needs Center (Hope School)

\section{Eksterior}

Eksterior Hope Special Needs Center (Hope School) secara tipologi tidak nampak sepeti bangunan sekolah pada umumnya melaikan lebih namak seperti sebuah bangunan kantor. Karena bangunan ini bukan bangunan tunggal yang berdiri sendiri, melaikan bagian dari blok perkantoran, sehingga massa bangunan yang terbentuk hanyalah gabungan dari persegi panjang yang terdiri dari 5 lantai. Hal ini yang menjadikan pula banguan Hope School tidak memiliki area ruang terbuka hijau.

Warna yang mendominasi pada eksterior Hope School adalah warna navy yang didapat dari warna kaca film yang menyelubungin bangunan ini. Warna navy memiliki sifat tenang, namun misterius. Walaupun warna navy dianggap warna yang formal, tetapi secara tipologi warna navy kurang cocok jika dijadikan warna dasar pada bangunan sekolah.
Karena bangunan Hope School ini merupakan bangunan jadi, sehingga Hope School ini paten dengan bentuknya yang persegi panjang dan hampir tidak memiliki gubahan bentuk. Elemen pada eksterior bangunan pun mengikuti bentuk persegi dan pengaplikasian material lainnya seperti pintu, jendela dan lainnya merupakan yang sudah terdapat pada bangunan. Berdasarkan pengamatan, warna maupun bentuk dari elemen eksterior bangunan memberi pengaruh berat, formal, dan tidak menyenangkan dikarenakan warna gelap yang mendominasi façade. [1,17]

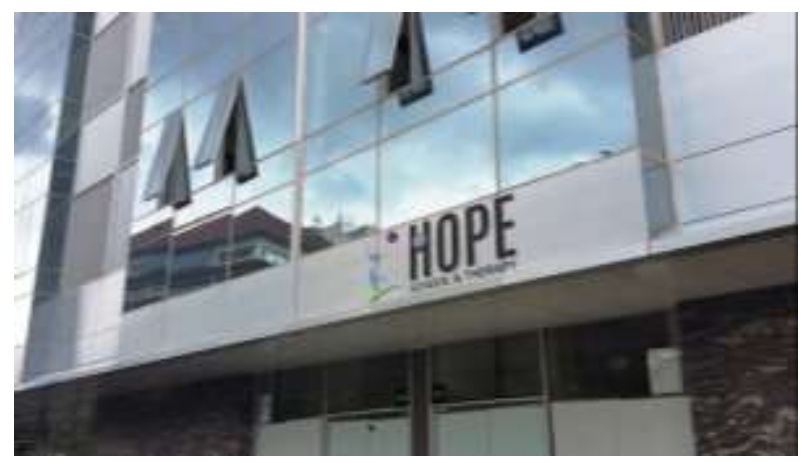

Gambar 9. Eksterior Hope Special Needs Center (Hope School)

\section{Interior}

Interior Hope Special Needs Center (Hope School) terdiri dari beberapa ruang dengan pembagian zona tiap lantainya. Pada lantai 1 terdapat ruang ruang lobby $\&$ resepsionis, area loker anak-anak, loker guru dan staff, ruang kelas Sunshine, ruang pimpinan, ruang alat musik, dan hall yang berfungsi juga sebagai amphitheater. Program ruang yang terdapat pada lantai 1 didominasi dengan warna cream pada dinding dan warna coklat pada lantai dengan material parquet. Warna cream yang digunakan pada interior Hope School merupakan warna pastel yang tenang (calm). Selain itu area ini memiliki suasana yang interaktif dengan aplikasi warna-warna fresh (segar) seperti hijau dan oranye. [10]

Permainan bentuk dan coakan pada dindingdinding interior juga sangat menarik. Yaitu mengadopsi bentuk outline sebuah rumah yang berjejer sehingga membuat kesan yang semakin ramah dan menyenangkan. Dengan suasana yang tenang namun tetap menyenangkan, maka secara visual akan berdampak terhadap fokus dan interaksi terhadap anak dengan disfungsi sensori. [4] 
Pembagian ruangan selain dengan dinding, yaitu menggunakan material kusen alumunium dan fiber transparan sebagai penyekat. Penggunaan material fiber transparent merupakan pengganti material kaca. Dikarenakan sifat kaca yang mudah pecah apabila terkena benturan, maka matrial fiber transparan pun dapat menjadi alternatif.

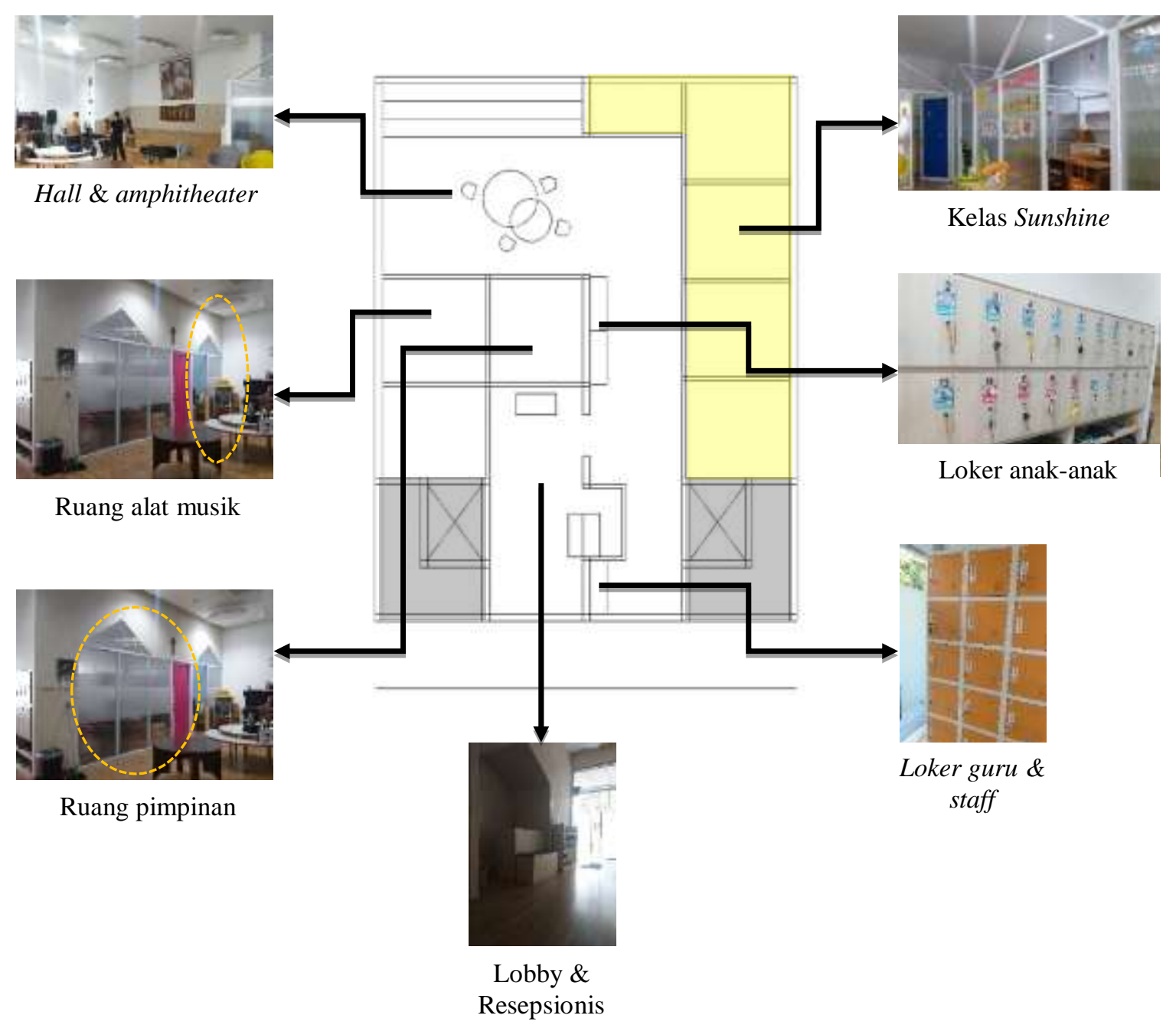

Gambar 10. Denah interior lantai 1 Hope Special Needs Center (Hope School) 
Pada lantai 2, terdapat ruang kelas Brightstar, ruang staff dan guru, ruang silent, mini library, area duduk, pantry dan ruang makan, dan toilet. Program ruang yang terdapat pada lantai 2 masih didominasi dengan warna cream pada dinding dan warna coklat pada lantai dengan material parquet. Meskipun masih didominasi dengan warna yang sama, area pada lantai 2 ini masih memiki unsur warna cerah lainnya yang dapat menarik perhatian secara visual. [4]
Berbeda dengan lantai 1, permainan bentuk dan coakan pada area lantai 2 ini tidak ditemukan. kali ini, area lantai 2 menyediakan mini library yang memiliki bentuk adaptasi dari bentuk sebuah pohon yang rindang. Hal ini sangat berpengaruh terhadap visual terutama pada anak dengan disfungsi sensori. Meskipun bentuknya unik, mini library pada lantai 2 ini juga memiliki bentuk yang ramah tanpa adanya sudut pada tepiannya.

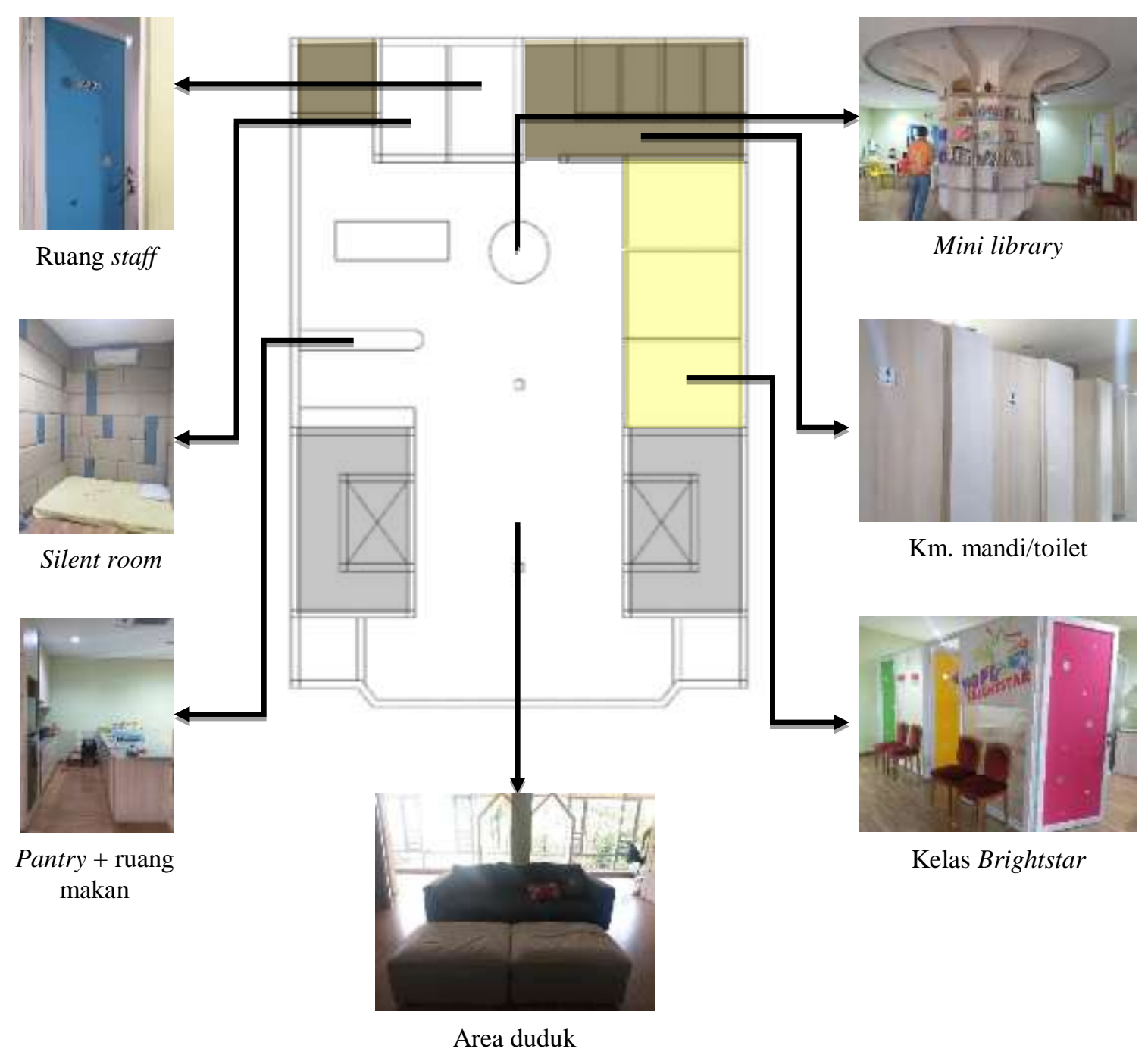

Gambar 11. Denah interior lantai 2 Hope Special Needs Center (Hope School) 
Berbeda dengan lantai 1 dan lantai 2, lantai 3 difokuskan hanya untuk ruang terapi sensori integrasi, senam, dan juga bermain. Warna yang ditampilkan pada seluruh area lantai ini juga berbeda dengan lantai sebelumnya, yaitu dengan mengaplikasikan warna hijau tosca dan masih tetap dengan lantai coklat parquet. Warna hijau tosca juga merupakan kelompok warna yang bersifat kalem (kelompok analogus) dan coklat pada lantai juga merupakan warna hangat dan netral. Sifat warna yang ada pada kedua warna dominan ini merupakan suatu katuan dari kelompok warna analogus dan komplementer. Sehingga pengaplikasiannya cukup baik bila diaplikasi pada ruang terapi yang bersifat gabungan, dalam kata lain tidak di khususkan bagi anak dengan gangguan hipersensori maupun hiposensori.

Meski dalam pengaplikasian warna sudah cukup berkaitan dengan pengaruh terhadap kemampuan visual anak autis, bentuk dan dan elemen yang terdapat pada yang tergolong sangat aktif ini, masih banyak ditemu material yang tidak ramah, seperti dinding dan lantai yang tidak dilapisi dengan matras atau material lunak lainnya. Mengingat karakter anak dengan gangguan sensori sangat sensitive dan memiliki tingkah laku yang unpredictable, sehingga tingkat waspada dan pengawasan aktifitas dalam ruangan ini harus lebih tinggi.

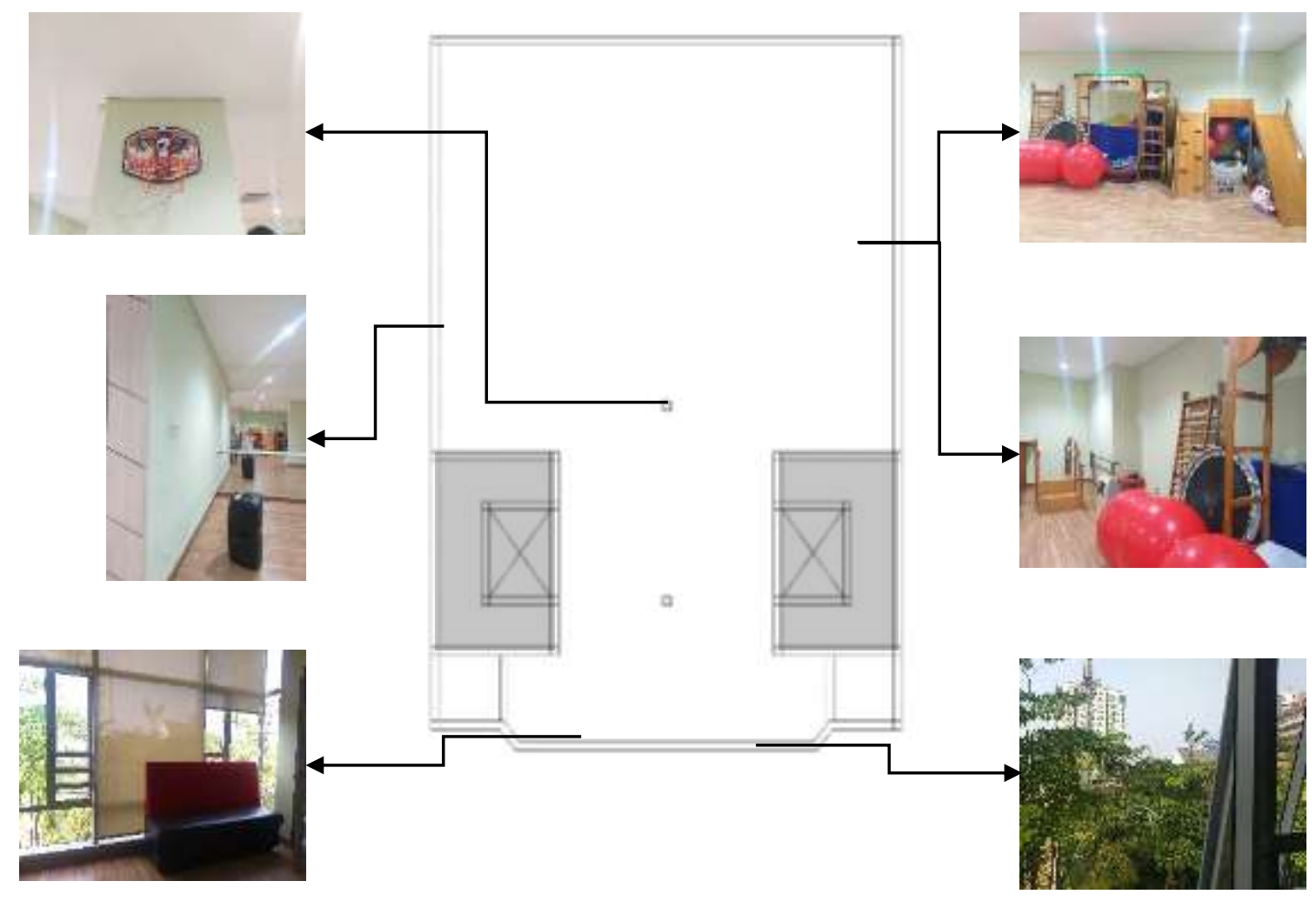

Gambar 12. Denah interior lantai 3 Hope Special Needs Center (Hope School) 
Pada bagian lantai 4, difokuskan sebagai area semulasi apartemen. Simulasi ruangan ini bertujuan agar anak ABK yang sudah cukup usia mampu hidup mandiri. Pada area simulasi apartemen ini terdapa ruang tamu yang berdekatan dengan ruang makan dan pantry, kamar anak, kamar pendamping juga ruang konseling, ruang simulasi mini theater, area dinding sensori, dan juga kamar mandi/toilet untuk anak dan guru pendamping.

Karena pada lantai 4 ini merupaka area simulasi apartemen dimana anak-anak dituntun untuk kemandirian, maka area yang ada di lantai 4 ini di desain layaknya hunian pada umumnya. Tidak ada elemen warna secara khurus, namun tetap menggunakan warna netral seperti putih, abuabu muda, atau cream. Pemilihan bentuk pada elemen ruangan seperti furniture pun juga layaknya hunian pada umumnya. Namun tetap beberapa furniture yang ada di ruangan ini merupaka benda/furniture dengan bentuk yang ramah.

Selain itu, yang menjadi daya tarik pada area ini ada terdapat ruang simulasi mini theater. Adanya ruangan ini bertujuan untuk mengetahui sejauh mana anak dengan gangguan sensori dapat beradaptasi dengan suasana yang gelap atau minim cahaya. Disisi lain, sebagaimana namanya ruangan ini juga menjadi simulasi bagi anak-anak yang hendak menonton film ke theater yang sesungguhnya.

Terdapat juga dinding sensori yang berfungsi sebagai estetika namun tetap dapat melatih sensori anak dengan pendekatan indera peraba tehadap tekstur yang ada pada hiasan-hiasan tersebut.

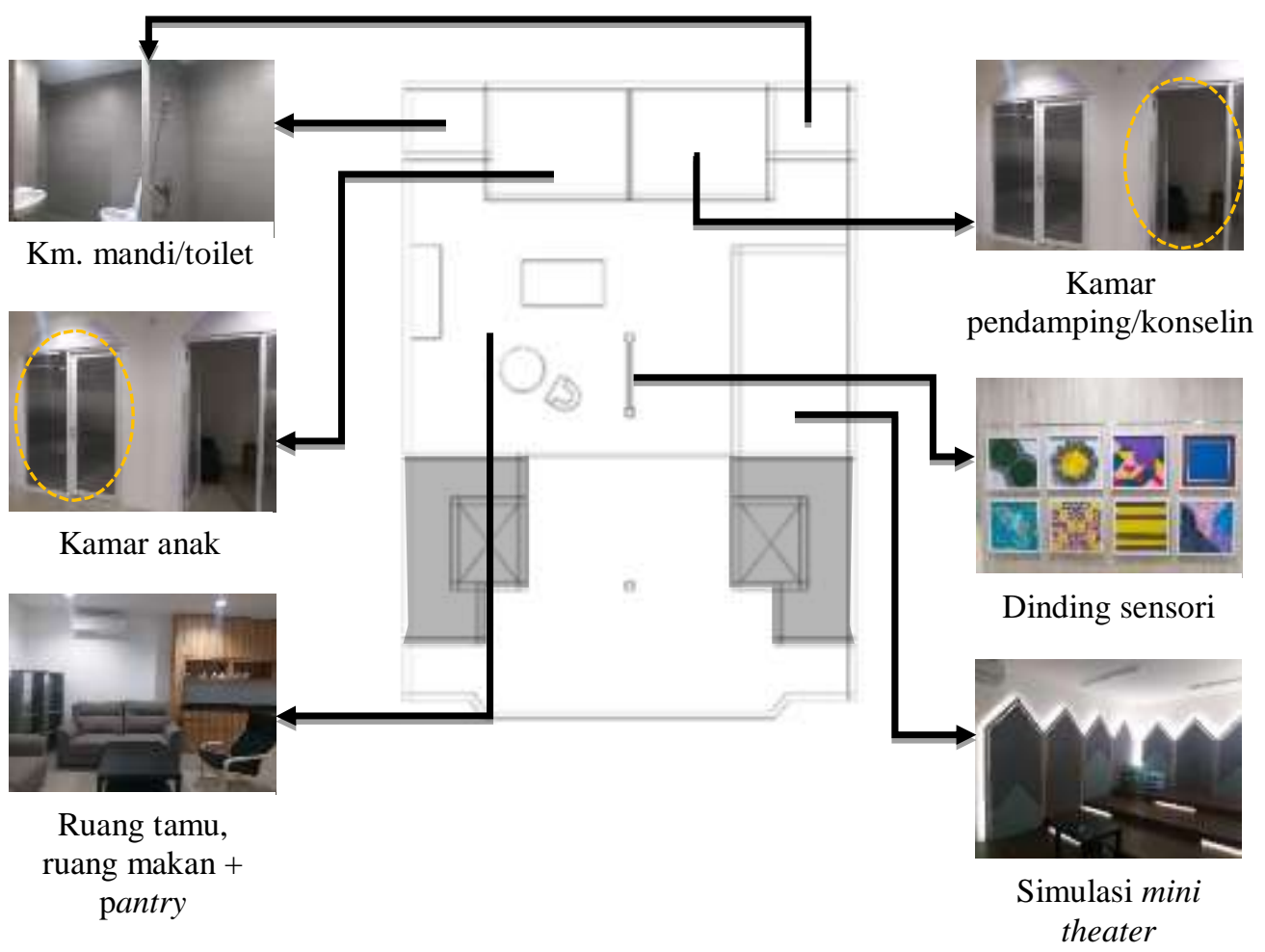

Gambar 13. Denah interior lantai 4 Hope Special Needs Center (Hope School) 
Lantai 5 merupakan lantai teratas pada Hope School ini. Pada lantai ini terdapat area cooking class dan art/gallery class. Terdapat pula wall/gallery corner sebagai wadah apresiasi terhadap kreasi dan karya anak-anak. Pada area ini warna yang diterapkan adalah warna putih. Warna putih diterapkan pada seluruh area ini karena dianggap netral dan polos. Sehingga tidak akan mengganggu fokus baik anak dengan gangguan disfungsi sensori [4]. Karena, pada area ini anakanak diharapan fokus dalam kegiatan masak dan juga saat kegiatan crafting.

Bentuk dan elemen yang ada di area lantai ini merupakan bentuk-bentuk biasa pada umumnya, tidak secara khusus ramah dan aman bagi anakanak dengan gangguan sensori, sehingga aktifitas anak-anak yang ada di area ini harus benar-benar terawasi.

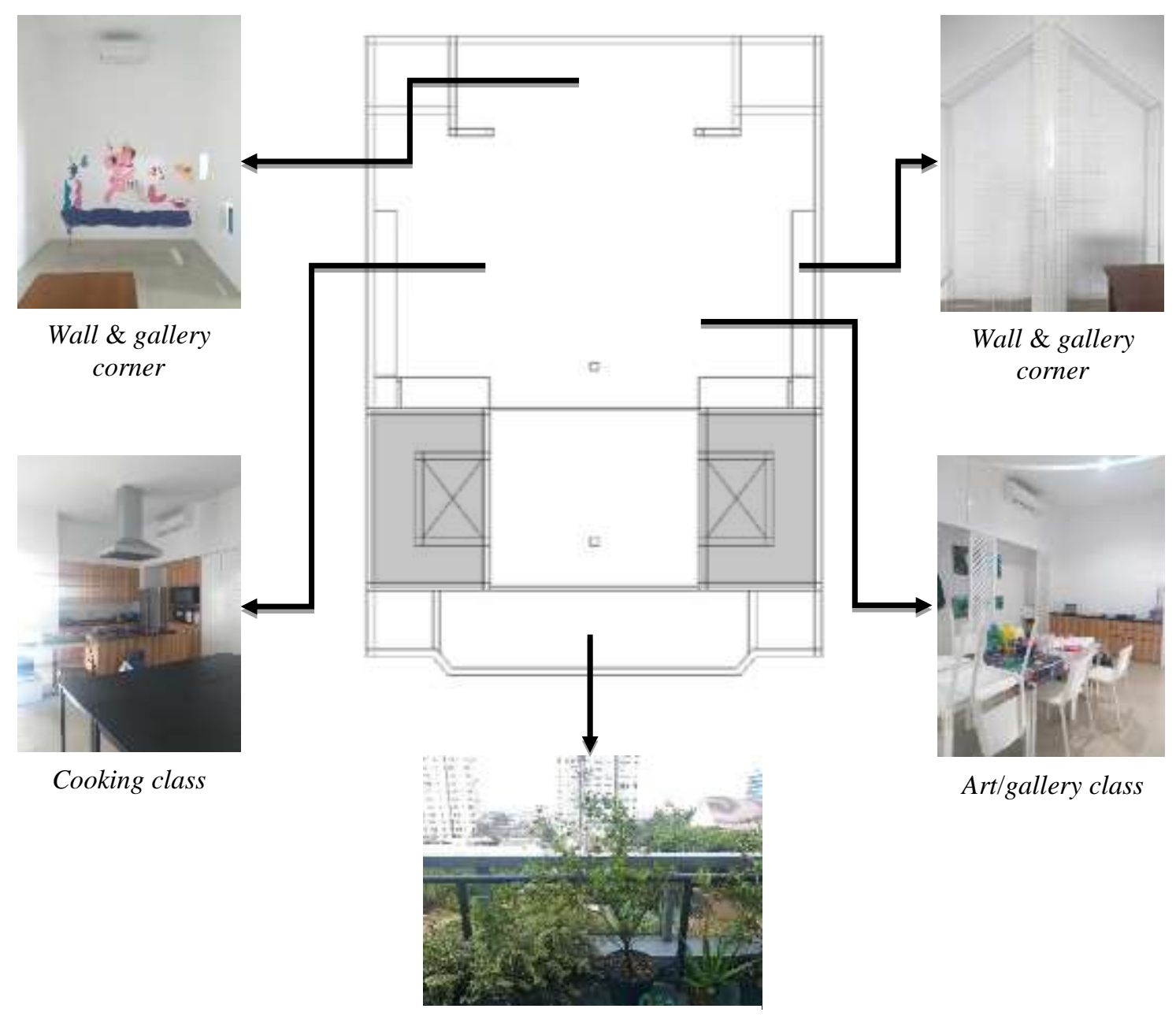

Balcony garden

Gambar 14. Denah interior lantai 5 Hope Special Needs Center (Hope School) 
Pada bagian depan di area lantai 5 ini terdapat balkon dengan kebun kecil yang sederhana. Spot ini merupakan satu-satunya area hijau yang dimiki Hope School. Area balcony garden ini juga sebagai sarana anak-anak untuk melatih kedisplinan dan tanggung jawab dalama merawat dan menjaga tanaman.
Pada tiap lantai bangunan Hope School ini juga dilengkapi dengan area service berupa tangga, lift, dan juga gudang yang ada ditiap lantainya.

Berdasarkan data yang didapat dari dua objek penelitian pada sekolah autis didapatkan kesimpulan yang dijelaskan pada tabel 2 .

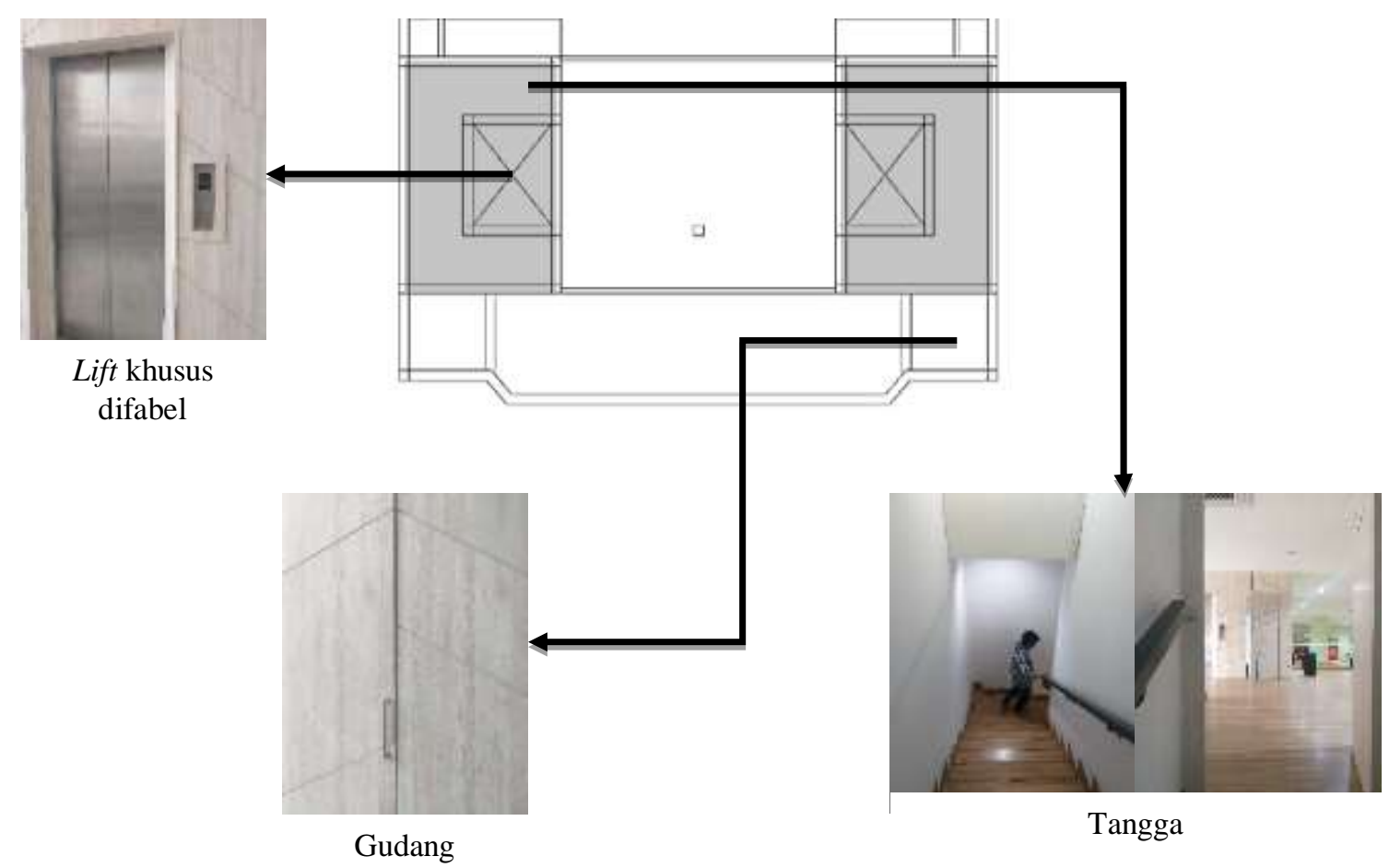

Gambar 15. Denah interior lantai 5 Hope Special Needs Center (Hope School) 
Tabel 2. Analisis perbandingan PSNC dan Hope School

\begin{tabular}{lll}
\hline \multicolumn{1}{c}{ Analisis } & \multicolumn{1}{c}{ PSNC } & \multicolumn{1}{c}{ Hope School } \\
\hline Site & $\begin{array}{l}\text { Kawasan Jababeka Education Park, } \\
\text { Cikarang }\end{array}$ & Kawasan Bisnis Altira, Sunter \\
\hline Jenis bangunan & Bangunan 1 lantai & Bangunan 5 lantai \\
\hline Ruang kelas & $\begin{array}{l}\text { Terbagi 3 jenis dengan tingkatan yang } \\
\text { berbeda-beda: }\end{array}$ & $\begin{array}{l}\text { Terbagi 2 jenis dengan tingkatan yang } \\
\text { berbeda: }\end{array}$ \\
& $\begin{array}{l}\text { - Ruang kelas mampu rawat, } \\
\text { - Ruang kelas mampu latih, } \\
\text { - Ruang kelas mampu didik }\end{array}$ & $\begin{array}{l}\text { - Kelas Sunshine (kemampuan dasar) } \\
\end{array}$ \\
& $\ldots$ &
\end{tabular}

\begin{tabular}{ll}
\hline Ruang terapi & $\begin{array}{l}\text { Memiliki 1 ruang t } \\
\text { dan } 4 \text { ruang ruang } \\
\text { terapi perilaku, tera } \\
\text { music dan ruang reme } \\
\text { Namum tidak mem } \\
\text { Snoezelen. }\end{array}$
\end{tabular}

(Ruang Terapi SI)
Memiliki 1 ruang terapi Sensori Integrasi yang juga digunakan sebagai ruang bermain dan senam. Selain itu memiliki 1 ruang silent, namun tidak detemukan ruang khusus untuk terapi-terapi lainnya.

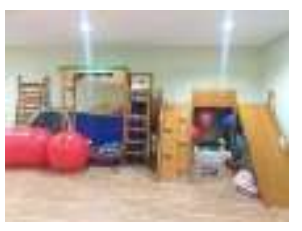

(Ruang terapi SI)

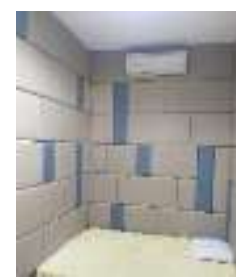

(Ruang Silent)
Ruang Tidak ada ruang luas/assembly luas/assembly
Terdapat ruang luas/assembly yang biasa digunakan untuk bernyanyi, bermain, bercerita bersama.

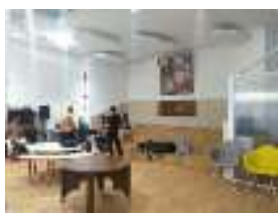

(Assembly room)

Pelingkup ruangan,
perkerasan,
penghubung
(selasar/taman/area
bersama, dll)

Pelingkup ruangan, Selasar (single loaded), taman yang luas, area bermain outdoor dan lapangan.
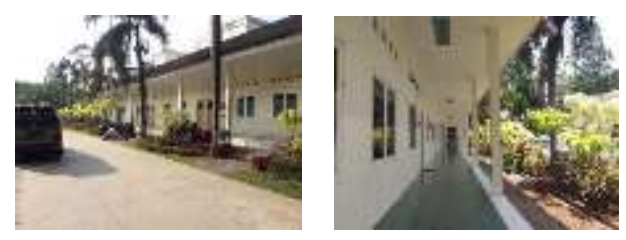

Memiliki

tangga dgn jalur sirkulasi yang baik, terdapat area duduk pada jendela yang memaksimaalkan bukaan untuk cahaya dan udara. Namun tidak memiliki area outdoor dan taman. 
PENERAPAN WARNA DAN BENTUK TERHADAP KEMAMPUAN VISUAL ANAK AUTIS SEBAGAI PERTIMBANGAN DESAIN

Berdasarkan data yang didapat dari dua objek penelitian didapatkan analisi warna dan bentuk terhadap kemampuan visual anak autis sebagai pertimbangan desain. Analisis yang dilakukan mengacu terhadap beberapa teori. Analisis dapat dilihat pada tabel 2 .

Tabel 3. Analisis penerapan warna dan bentuk terhadap kemampuan visual anak autis sebagai pertimbangan desain

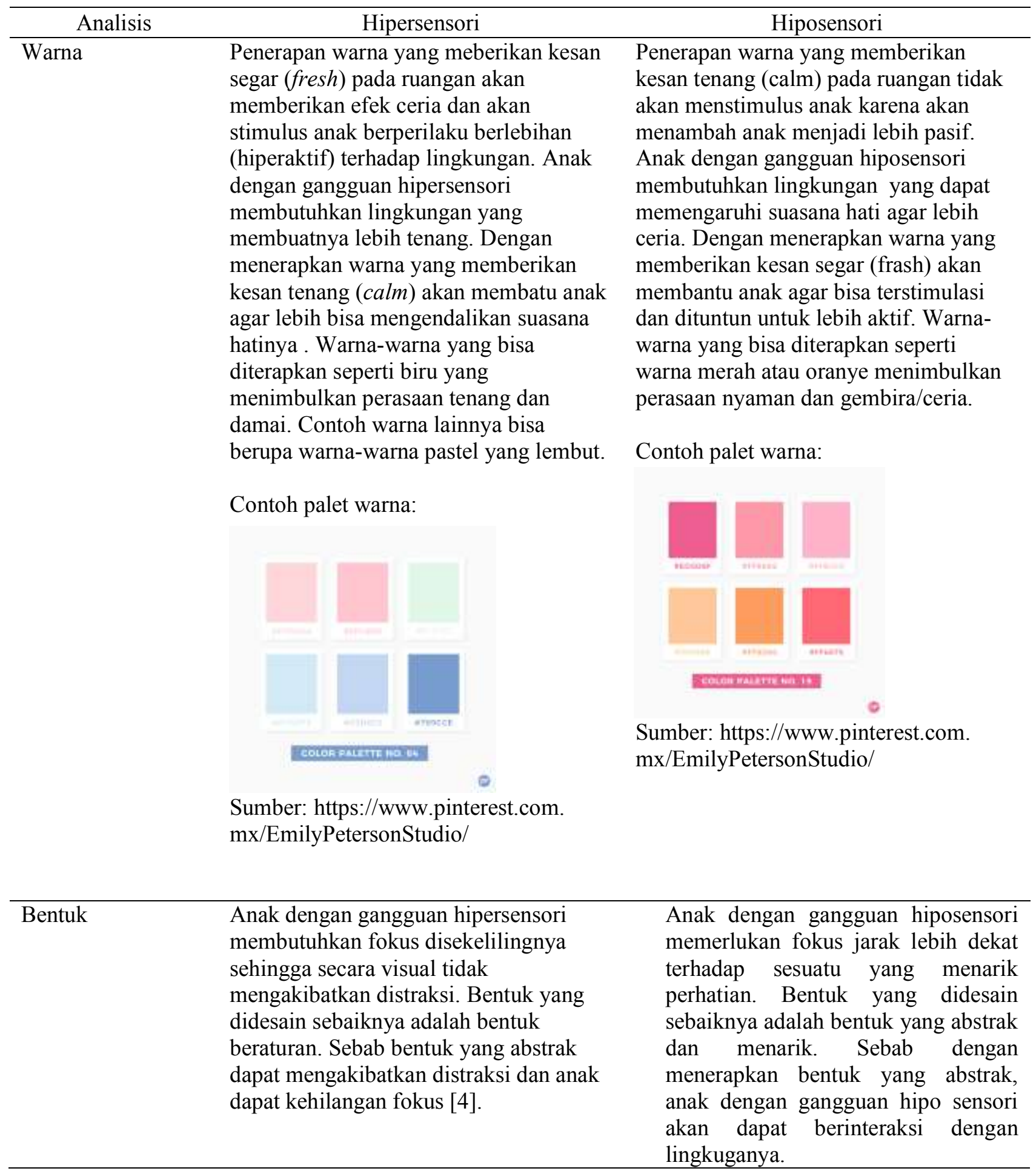




\section{Warna}

Penggunaan warna dapat memengaruhi kondisi suasana hati (mood) dan kretifitas seseorang. Tidak hanya itu, warna juga dapat memberikan efek psikologis bagi manusia. Bagi anak dengan gangguan autis, penggunaaan warna menjadi salah hal yang harus diperhatikan. Mengingat kemampuan anak autis masing-masing memiliki masalah integrasi yang berbeda-beda maka kebutuhan dari tiap harus disesuaikan berdasarkan klasifikasi disfungsi sensorinya.

\section{Bentuk}

Selain tekstur dan material yang harus diperhatikan, Penerapan bentuk itu sendiri sebaikan bentuk yang mudah dipahami oleh anak autis. Hal ini dikarenakan anak autis sulit untuk membayangkan dan menerima informasi mengenai bentuk yang dilihatnya. Bentuk yang beraturan cukup baik bila diaplikasikan pada elemen ruangan. Selain itu akan memberkan kesan rapi. Sedangkan bentuk yang abstrak akan membuat distraksi bagi anak autis. Tidak hanya bentuk itu sendiri namum, tektur dan material dari bentuk tersebut harus dipehatikan agar tidak berbahaya bagi anak autis.

Ragam bentuk dengan berbagai tekstur juga dapat melatih kepekaan dan motorik anak autis dalam mengenal bentuk dan tekstur permukaan. Contohnya seperti penerapan dinding sensori yang terdapat pada Hope School.

\section{KESIMPULAN DAN SARAN}

Berdasarkan analisis yang dilakukan tenang warna dan bentuk terhadap kemampuan visual anak autis pada fasilitas pendidikan, maka dapat disimpulkan bahwa aplikasi warna pada sebuah fasilitas bangunan dapat memengaruhi psikologi dan memberi pengalaman atau kesan bagi masingmasing anak autis. Disamping itu. tiap anak autis memiliki kebutuhan dan daya tangkap yang berbeda-beda tergantung gangguan sensorinya (disfungsi sensori) sehingga ruang-ruang yang disediakan harusnya disesuaikan dengan kebutuhan anak dengan tiap gangguannya (hipersensori maupun hiposensori). Hal ini bertujuan agar penyampaian informasi terutama secara visual dapat mudah diterima oleh anak dan juga akan berpengaruh baik terhadap kondisi psikologinya. Oleh karena itu kebutuhan ruang sosialisasi atau assembly room sangat penting mengingat anak dengan gangguan autis memiliki masalah interaksi sosial. Selain itu, ruang terapi sebaiknya dipisah antara ruang terapi untuk individu dan ruang terapi kelompok.

\section{DAFTAR PUSTAKA}

[1] Birren, F (1961) Colour Psychology and Colour Therapy. New York: University Book Inc.

[2] Ching, Francis D K (1996) Arsitektur: Bentuk, Ruang, dan Tatanan. Jakarta: Erlangga.

[3] Coulter, Rachel A (2009) Understanding the Visual Symptoms of Individuals with Autism Spectrum Disorder (ASD). OH, United States: Optometry \& Vision Development (OVD) Journal Volume 40.

[4] Dyah Septia, Lily Mauliani, Anisa (2016) Pengaruh Perilaku Penyandang Autis terhadap Desain Ruang Dalam Studi Kasus : Bangunan Pendidikan.

[5] Gheista I, Rinawati P H, Triandi L (2014) Penerapan Warna dan Cahaya pada Interior Ruang Terapi Dasar dengan Pendekatan Visual Anak Autis.

[6] Gunardi, Tri (2008) Teori Sensori Integrasi Up Date untuk Anak Autis. Autism Awareness Festival 18 September 2008. Jakarta.

[7] Habsari, S U (2010) Aplikasi Semiotik \& Efek Psikologis Tampilan Warna pada Rumah Minimalis.

[8] Hadis, Abdul (2006) Pendidikan Anak Berkebutuhab Khusus-Autistik. Bandung: Alfabeta.

[9] Huwaida L, Kristianto, T A (2016) Desain Interior Malang Eye Center sebagai Pusat Kesehatan yang Bersahabat. Jurnal Sains dan Seni ITS.

[10] KP, RM Bambang Setyohadi (2010) Pengaruh Warna terhadap Kamar Tidur Anak.” Jurnal Teknik Sipil \& Perancangan.

[11] Lawson, Wendy (2005) Sensory Issues in Autism. UK: The Autism and Practice GroupLearning Disability Services.

[12] Littlejohn, Stephen W (1995) Theories of Human Communication. A Student Guide. fifth edition, United States of America.

[13] Merry (2008) Studi Desain Interior Pusat Terapi Anak Berkebutuhan Khusus pada Sekolah SAFIR di Surabaya.

[14] Milne, Elizabeth (2007) Visual Perception and Visual Dysfunction in Autism Spectrum Disorder: A Literature Review. British and Irish Orthoptic Journal Volume 4 15-20.

[15] Mostafa, Magda (2008) An Architecture for Autism: Concept of Design Intervention for the Autistic User. Archnet-International Journal of Architecture Research (IJAR), Vol.2 189-211. 
[16] Mukhtar (2013) Metode Penelitian Deskriftif Kualitatif. Jakarta: GP Press Group.

[17] Pile, John F (1995) Interior Design. New York: Harry N. Abrams In.

[18] Rahmana, Thyyo S (2013) Teori Tentang Bentuk Arsitektural.

The 2019 the Author(s), licensee Jurnal LINEARS. This is an open-access article distributed LINEAS under the terms of the Creative Commons Attribution License

(http://creativecommons.org/licenses/by/4.0) 